Kodifikasia : Jurnal Penelitian Islam, Vol 14, No. 01 (2020), 21-41

DOI : 10.21154/kodifikasia.v14i1.1802

ISSN : 1907-6371 (Cetak)

ISSN : 2527-9254 (Online)

\title{
SANTRI, JIHAD, DAN RADIKALISME BERAGAMA: IMPLIKASI ATAS PENAFSIRAN AYAT JIHAD
}

\author{
Alfi Qonita Badi'ati*
}

\begin{abstract}
ABSTRAK:
Santri, jihad, dan radikalisme adalah satu kesatuan yang digambar sebagai lingkaran pengontrol dalam beragama, pun bisa berlaku sebaliknya. Santri (orang yang tinggal di pesantren) dipahami sebagai orang yang mengerti dasar- dasar agama. Pemahaman tetang jihad adalah konsep dasar yang menuntun seseorang untuk melakukan tindakan radikalisme. Dan Toleransi adalah hasil dari pemahaman jihad berdasarkan ajaran Islam tersebut yang kemudian dimaknai sebagai Islam rahmatan lil 'alamin. Penelitian ini bertujuan untuk mengetahui sejauh mana pemahaman santri terhadap makna jihad, yang kemudian berdampak pada tindakan radikalisme beragama. Penelitian dengan pendekatan field research ini menggunakan sampel para santri dari berbagai tipe pesantren (salaf, khalaf, dan campuran) di Kabupaten Semarang. Studi ini menemukan bahwa semua santri memiliki benih radikalisme, meskipun masih dalam taraf pemahaman, pun ada yang sudah dalam tindakan. Ini dipengaruhi beberapa faktor penting; jenis pesantren, pendidikan dan kurikulum yang diterima, bahan bacaan, serta keadaan lingkungan santri tinggal. Ada beberapa alternatif untuk mengurangi pergerakan intoleransi dan radikalisme; melalui lingkungan dengan pemahaman Islam yang baik, pendidikan agama yang moderat, serta pengamalan konsep Islam yang rahmatan lil 'alamin.
\end{abstract}

Kata Kunci: Santri, Jihad, Radikalisme, dan Toleransi.

\footnotetext{
* Institut Agama Islam Negeri Salatiga, email: alfiqonita@iainsalatiga.ac.id
} 


\begin{abstract}
ABSTRACK:
Santri, jihad, and radicalism are the unity which illustrates as the controlling circle in religion, and can be applied vice versa. Santri (Islamic boarding school student) is understood as a person who understands the basics of religion. An understanding of Jihad is a basic concept that leads someone to be radical. Tolerance is the result of the understanding of jihad based on Islamic teachings wholeheartedly, and called rahmatan lil 'alamin. The aim of this reseacrh is to determine the understand of santri about the means of Jihad which is becames a religious radicalism. The kind of this research is field research, which is the sampling is santri from all the type of pesantren (salaf, khalaf, and mixed) in Semarang district. The result of this study is that all of santri has the potential of radicalism, even still in their understood. There are some factors such as the model of pesantren, education system that received, or at least from the results of dissemination of the reading, and the neighbourhood. There are also several alternatives to reduce the movement of intolerance and radicalism. Starting from a good family environment, moderate religious education, and understanding the concept of rahmatan lil amin alamin in Islam.
\end{abstract}

Keyword: Santri; Jihad; Radicalism; Tolerance.

\title{
PENDAHULUAN
}

Kekerasan atas nama agama semakin menjamur terjadi di Indonesia bahkan di dunia. Reformasi dan demokratisasi menjadikan lahirnya bermacam organisasi dan perkumpulan politik. Berakhirnya rezim Orde Baru membawa arus perubahan demokratisasi yang diikuti dengan terciptanya ruang kebebasan pers, aksi, dan gerakan protes sosial semakin bebas. Adanya kelompok Islam Puritan menyisakan persoalan kemasyarakatan di Indonesia yang berlatar belakang kebinekaan. ${ }^{1}$ Sering kali sikap intoleran terhadap pemeluk agama lain, atau pemikiran yang berbeda menimbulkan kegelisahan di masyarakat. Corak keberislaman yang menunjukkan sikap fanatik dan ekslusif sering memaksakan pemahaman dan menganggap golongannya paling benar. Sikap tersebut melahirkan radikalisme dalam

${ }^{1}$ Giora Eliraz, Islam and Polity in Indonesia: An Intriguing Case Study (London: Hudson Institute, 2007), 2.

Kodifikasia: Jurnal Penelitian Islam, Volume, 14 No. 1 Tahun 2020 
beragama dan akan menjadi bahaya ketika dipaksakan pada pemeluk agama lain. $^{2}$

Berbagai aksisweeping atribut non-muslim yang dikenakan muslim pada saat peringatan hari besar agama lain, gerakan anti maksiat yang berujung anarkis, saling tuduh mengkafirkan, membid'ahkan, dan segala aksi reaksi yang berbuntut pada tindakan ekstrim yang mengatasnamakan jihad fisabilillah. Gerakan Islam radikal selalu ada hubungannya dengan pemahaman mereka mengenai ayat-ayat jihad dalam menegakkan amar ma'ruf nahi mungkar. Menurut Teori Kekuasaan, gerakan radikal juga selalu berhubungan dengan agenda politik praktis atau politik kekuasaan mempertahankan atau menghancurkan kekuasaan yang dinilai menghalangi tercapainya agenda politik mereka. Dalam rangka merebut kekuasaan, atau mendirikan Negara Islam mereka tidak segan-segan untuk menggunakan berbagai cara termasuk cara-cara kekerasan dan tindakan kriminal. Kondisi tersebut tidak hanya terjadi pada masa sekarang. Sejarah mencacat, hal tersebut sudah terjadi pasca wafatnya Rasulullah SAW. ${ }^{3}$

Banyak faktor yang bisa membentuk karakteristik seseorang menjadi radikal, seperti faktor pendidikan, ekonomi, lingkungan termasuk ideologi politik yang berkembang dilingkungannya. Dengan asumsi bahwa radikalisme dan terorisme juga disebabkan oleh paham keagamaan yang keliru. Hal ini juga bisa terjadi karena munclnya paradigma berfikir yang dibentuk oleh tafsir literal. Munculnya beberapa kelompok yang kemudian memproklamirkan diri mereka menjadi nabi baru, juga ditelusuri banyak yang memakai tafsir literal tekstual. ${ }^{4}$

Pemikiran yang kemudian mengarah pada tindakan radikal tersebut tidak terlepas dari pemahaman seseorang dalam memahami makna jihad. Jihad difahami sebagai sebuah kewajiban setiap muslim. Hal ini berdampak pada tindakan yang kemudian dilakukan seseorang sebagai wujud melaksanakan kewajiban tersebut. Jihad dijelaskan oleh banyak golongan sebagai bentuk pergerakan untuk mempengaruhi orang lain menjadi lebih baik. Namun, pada praktiknya, bentuk ajakan tersebut bisa melukai, dan bahkan mengambil nyawa orang yang diajak. Jihad yang dilakukan oleh sebagian oknum tersebut mengaburkan makna jihad yang sebenarnya. Islam yang memiliki nilai kedamaian dan kesalamatan tertutup dengan tindakan yang mendasarkan pada perbuatan jihad. Jika tidak segera diluruskan, bisa jadi akan semakin banyak korban berjatuhan.

\footnotetext{
${ }^{2}$ Emna Laisa, "Islam Dan Radikalisme," Islamuna 3 (2014): 3.

${ }^{3}$ Muhammad Umar Jiau Al-Haq, Mencermati Aliran Sesat: Rekonstruksi Pemahaman Islam, (Bandung: Pustaka Islamika, 2011), 9.

4 Al-Haq, 7.
} 
Sikap demikian tentunya tidak bisa lepas dari cara pandang terhadap doktrin suatu ajaran. Cara pandang tersebut tidak bisa lepas dari pendidikan yang diterima, atau paling tidak dari hasil diseminasi atas bacaan tentang sesuatu ajaran yang dipelajarinya. Dari sini nampaknya pendidikan merupakan entitas terpenting dalam pembentukan karakter dan sikap keagamaan seseorang. penelitian akan memfokuskan pada pengajaran atau paham keagamaan yang dikembangkan dalam pesantren.

Pondok pesantren merupakan salah satu lembaga pendidikan tertua yang menjadi ciri khas Islam tradisional Indonesia. Eksistensi keberadaan masyarakat Islam di Indonesiaberkaitan eratdengan adanya proses asimilasi, akulturasi, dan sincretisme. ProsesIslamisasiterjadi melalui pendekatan dan penyesuaian dengan unsur-unsur kepercayaan yang sudahadasebelumnya. Proses ini melalui berbagai macam cara antara lain melalui perdagangan, perkawinan, pondok pesantren, kebudayaan, dankesenian. Dalam hal ini, pesantren memiliki peran penting sebagai tempat belajar dalam memahami, menghayati, dan mengamalkan nilai-nilai ajaran Islam. ${ }^{5}$

Diantara institusi yang dianggap mampu menjawab persoalan keagamaan yang terus berkembang di Indonesia ini adalah pesantren. Dalam realitasnya, Pesantren masih tetap eksis dalam dinamika modernitas. Pesantren telah mampu menunjukkan dirinya sebagi lembaga yang bisa beradaptasi dengan perkembangan zaman tanpa kehilangan identitas dirinya sendiri.Pendidikan di pesantren berperan besar dalam pembangunan karakter di Indonesia. Pondok pesantren selama ini telah teruji sebagai lembaga yang turut membentuk akhlaq dan kepribadian bangsa. Nilainilai tersebut merupakan hasil dialektika yang dinamis antara nilai-nilai keagamaan yang bersumber pada teks yang diajarkan di dalamnya. ${ }^{6}$

Pesantren pada umumnya, mengajarkan budaya damai dan lebih banyak menampakan karakter Islam yang moderat. Menurut Abdurrahman Mas'ud $^{7}$ komunitas pesantren pada umumnya bebas dari fundamentalisme, radikalisme dan terorisme. Pesantren dijadikan sebagai benteng strategis menangkal berkembangnya paham radikal di kalangan umat Islam. Upaya tersebut didasarkan atas filosofi tradisi pesantren, fakta di lapangan, serta beberapa hal yang menyebabkan berkembangnya gerakan radikalisme.

\footnotetext{
${ }^{5}$ Ridlwan Nasir, Mencari Tipologi Format Pendidikan Ideal: Pondok Pesantren Di Tengah Arus Perubahan (Yogyakarta: Pustaka Pelajar, 2010), 86.

6 Thaha Chatib M, Strategi Pendidikan Islam Dalam Mengembangkan Manusia Indonesai Yang Berkualitas (Yogyakarta: IAIN Walisongo, 1990), 33.

7 Abdurrahman Mas'ud, "Memahami Agama Damai Dunia Pesantren," in Peranan Pesantren Dalam Mengembangkan Budaya Damai, ed. Nuhrison (Jakarta: Badan Litbang dan Diklat Kementrian Agama, 2010), 23.
} 
Maka, santri dipandang sebagai agen yang paling tepat dalam menyebarkan nilai-nilai toleransi dan moderasi di negeri ini.

Kasus radikalisme ini juga berkembang pesat di Wilayah Kabupaten Semarang. Padahal wilayah Kabupaten Semarang tercatat memiliki banyak sekali pesantren dengan beberapa jenis (salaf, khalaf, dan campuran). Selain itu yang menjadi menarik adalah, Kabupaten Semarang menjadi wilayah perbatasan antara Solo dan Salatiga. Salatiga yang terkenal sebagai kota toleransi ke dua, sedang Solo adalah kota yang sangat kompleks dengan kelompok organisasi keagamaan yang begitu banyak. Maka penulis mengambil objek pada pemahaman santri mengenai makna jihad di wilayah Kabupaten Semarang.

\section{PEMBAHASAN}

\section{Dialektika Makna Jihad}

Kata jihad adalah satu di antara beberapa kata yang mengalami pergeseran makna. Jihad, oleh kalangan awam diartikan sebagai perang, mengangkat senjata, dan terkadang sampai makna bom bunuh diri. Dalam buku The religion of Islam, FA Klein sebagai penulis, menyatakan bahwa: "Jihad merupakan bentuk perang melawan kaum kafir yang bertujuan memaksa mereka memeluk agama Islam, atau menindas dan membinasakan mereka jika mereka menolak menjadi orang Islam, menyiarkan dan memenangkan Islam di atas sekalian agama dianggap sebagai tugas suci umat Islam".

Makna jihad menjadi sesuatu yang kontroversial pada satu dekade terakhir. Ini terjadi karena banyaknya peristiwa yang dilakukan oleh para muslim Indonesia, bahkan dunia yang melakukan tindakan kekerasan berlandaskan kata jihad. Para cendikiawan kemudian bermunculan, baik yang pro terhadap jihad bi makna kebolehan untuk melakukan kekerasan dan sebagian lagi yang tidak menyetujui pemahaman jihad sebagai bentuk penindasan. Formulasi konsep jihad terus dirumuskan, agar tidak semakin salah dalam memahami dan melaksanakannya dalam kehidupan. ${ }^{8}$

Pemaknaan jihad sebagai qital, perang, dan kekerasan sering muncul dari golongan outsider. Hal tersebut tidak bisa serta merta disalahkan, karena dari kalangan muslim pun masih banyak yang memaknai jihad harus dengan mengorbankan harta, keluarga, dan bahkan nyawa banyak orang. ${ }^{9}$ Menurut Ibnu Manzur dalam Lisanul Arab mengartikan kata Jihad dengan (perkara sungguh-sungguh yang dimiliki manusia dari sakit ataupun perintah yang sulit), المشقة (usaha, jerih payah, kesukaran), الطاقة

${ }^{8}$ Khamami Zada, Islam Radikal: Pergulatan Ormas-Ormas Islam Garis Keras Di Indonesia (Jakarta: Teraju, 2002), 34.

${ }^{9}$ Maulana Muhammad Ali, Islamologi (Dinul Islam) (Jakarta: PT Ichtiar Baru - Van Hoeve, 1980), 75. 
(kemampuan). ${ }^{10}$ Sedang Muhammad bin Abi Bakar bin 'Abdi al-Qadir al-Razi dalam Mukhtar al-Shahâh yang menyebutkan jihad berasal dari kata al-juhd artinya al-tâqah, atau al-jahd artinya almasyaqqah. ${ }^{11}$ Dengan demikian, asal kata jihad adalah al-jahdu dengan mem-fathah-kan huruf jim atau al-juhdu dengan mendhammah-kan huruf jim, yang artinya altâqah (kekuatan), al-wus'u (usaha) dan al-masyaqqah (kesulitan).

Pembahasan tentang suatu hal pokok dalam Islam, secara normatif harus merujuk pada akar sejarah kata tersebut muncul. Pada masa nabi, kata jihad sering digunakan baik dalam pembahasan ataupun pada konteks tindakan. Pun disesuaikan dengan keadaan nabi dan para sahabat. Penyebaran Islam pada zaman nabi tentulah berhubungan dengan dua kota agung, Makkah dan Madinah. Dua kota tersebut menjadi saksi perjalanan hidup nabi Muhammad dalam mengajarkan Islam kepada umatnya.

Para ulama bersepakat, bahwa pembagian turunnya ayat dalam ilmu al-Qur'an dan tafsir berdasar pengkategorian ayat Makkiyyah, dan Madaniyah. Pengkategorian tersebut pada dasarnya tidak ada perintah yang mengharuskan, akan tetapi merupakan perkara yang bersifat ijtihadi. Beberapa di antara ciri ayat makkiyyah yang berkenaan dengan tema jihad adalah gaya bahasa yang efektif, variatif, dan juga dialogis. Ketika al-Qur'an turun di Makkah ayat-ayat yang tentang jihad menjelaskan mengenai prinsip-prinsip dasar ajaran Islam.

Istilah jihad sudah digunakan pada periode Makkah. Pelacakan ini bisa diketahui berdasarkan pada identifikasi ayat yang disusun sesuai urutan turunnya (tartib nuzuly). Istilah jihad dan derivasinya pada periode Makkah menekankan pada implikasi jihad untuk berdakwah, seperti perintah untuk berdialog dengan kaum Quraisy Makkah dengan dialog yang baik. Hal ini bertujuan agar ajaran Islam dapat diterima dengan baik. Seperti dalam firman Allah surat al-Furqan (25) ayat 52 yang artinya: maka janganlah kamu mengikuti orang-orang kafir, dan berjihadlah terhadap mereka dengan $\mathrm{Al}$ Qur'an dengan jihad yang besar.

Periode makkah merupakan masa perjuangan umat Islam untuk mempertahankan akidah mereka. Pada periode ini dibutuhkan kesabaran untuk mempertahankan keimanan mereka. Dalam literature sejarah diceritakan bahwa umat Islam Makkah menghadapi banyak gangguan dari orang kafir. Gangguan baik secara langsung maupun tidak langsung karena secara kuantitas umat Islam masih sedikit. Secara ajaranpun akidah yang dibawa Muhammad bertentangan dengan ajaran nenek moyang mereka.

${ }^{10}$ Ibn Mandzur, Lisân Al-Aarab (Kairo: Darul Ma'arif, 1119), 708.

${ }^{11}$ Muhammad bin Abi Bakar bin 'Abdi al-Qadir Ar-Razi, Mukhtar Al-Shahâh (Beirut: Maktabah Lubnân, 1986), 48. 
Dalam al-Qur'an Surat Fatir (35): 42, Al-Nahl (16): 38 dan Al-An'am (6): 109 menggunakan redaksi yang sama dan memiliki arti kesungguhan. Kesungguhan yang dimaksud dalam ayat tersebut adalah kesungguhan orang kafir yang sebelumnya berjanji ketika suatu saat datang seorang nabi yang memberi peringatan maka mereka akan beriman dan mengikuti ajarannya. Namun ketika datang utusan, mereka mengingkarinya ${ }^{12}$

Jihad pada periode Mekkah juga ada yang berarti perdebatan. QS.29:8 menyatakan: "Dan Kami wajibkan manusia (berbuat) kebaikan kepada duaorang ibu-bapaknya. Tetapi jika mereka bertengkar (jahada) dengan engkau supaya engkau menyekutukan Aku, yang engkau tidak mempunyai pengetahun, janganlah enkau taat kepada mereka."Menjelang berakhirnya periode Mekkah, turun ayat 110 surat al-Nahl yang terjemahannya: "Sesunggunya Tuhanmu (pelindung) bagi orang-orangyang berhijrah sesudah mereka difitnah, kemudian mereka berjihad dan sabar; sesungguhnya Tuhanmu sesudah itu benarbenar Maha Pengampun lagi Maha Penyayang." Ayat yang terakhir ini lebih menegaskan lagi bahwa jihad bukansesuatu yang bertentangan dengan sabar. Jihad dan sabar memang harus selalu berdampingan.

Dari beberapa keterangan di atas terlihat bahwa jihad dalam al-Qur'an dilakukan secara bertahap. Ayat-ayat yang turun di Makkah menunjukkan ayat jihad dimaknai sebagai kesungguhan diri dalam mempertahankan iman. Tantangan untuk mempertahankan diri dalam keadaan iman merupkan bagian jihad terberat dalam masa tersebut.

Perintah jihad dengan mengangkat senjata untuk mempertahankan agama dan Negara baru diwajibkan setelah kaum muslimin hijrah ke Kota Madinah. Kata jihad pada periode Madinah tetap digunakan untuk menunjuk penegertian yang lebih luas meliputi kesungguhan dan perjuangan dengan apa saja. Diantara ayat yang memberikan gambaran jihad yang turun pada periode Madinah adalah ayat QS 9:73 dan QS 66:9. Terjemahan kedua ayat itu sebagai berikut: "Wahai nabi berjihadlah melawan orang-orang kafir dan orang-orangmunafik dan bersikap keraslah terhadap mereka. Tempat mereka adalah neraka Jahannam dan itu adalah seburuk-buruk tempat kembali".

Menurut ayat ini, nabi diperintahkan berjihad melawan kaum kafir dan kaum munafik. Kaum munafik ialah orang yang lahiriahnya muslim dan hidup ditengah-tengah kaum muslimin dan diperlakukan sebagai orang Islam dalam segala hal. Mereka pergi ke mesjid dan menjalankan shalat bersama kaum muslimin. Bahkan mereka juga membayar zakat. Memerangi mereka adalah tidak mungkin dan perang tak pernah dilakukan terhadap

${ }^{12}$ Wahbah Az-Zuhaili, Tafsir Al-Munir Fi Al- 'aqidah Wa asySyar `iah Wa Al-Manhaj (Damaskus: Darul Fikri, 1991), 242 dan 441. 
mereka. Bahkan terkadang mereka bertempur bersama kaum muslimin melwan kaum kafir. Oleh sebab itu perintah untuk melakukan jihad terhadap kaum kafir dan kaum munafik tak mungkin diartikan perang terhadap mereka. Jihad di sini mempunyai arti yang sama dengan kata jihad yang digunakan pada ayat-ayat periode Mekkah yakni jihad dengan al-Qur'an disertai usaha sekuat tenaga agar mereka orang kafir dan orang munafik tertarik terhadap Islam.

Kata jihad pada ayat-ayat periode Madinah juga berarti umum, yakni berjuang meskipun perjuangan itu bisa mencakup pertempuran. QS 2: 218. Terjemahannya berbunyi sebagai berikut: "Sesungguhnya orang-orang yangberiman, orang-orang yang berhijrah dan berjihad di jalan Allah, mereka itu mengharapkan rahmat Allah, dan Allah Mahapengampun lagi Maha Penyayang." Ibnu Mandzur (630-711H/1232-1311 M.) dalam penelitiannya terhadap kata jihad serta kata yang memliki akar kata yang sama menyimpulkan bahwa makna kata jihad selalu berkisar pada dua pengertian yakni aljuhd (usaha dengan sungguh-sunguh) dan al-jahd (tekad yang kuat untuk mengatasi hambatan dan kesulitan-kesulitan).

Perintah jihad dengan berperang, dimulai pada abad ke-dua hijriyah tepatnya perintah jihad yang termanifestasi dalam perang badar. Rasulullah menyerukan kepada para sahabat untuk berjihad dengan berperang melawan orang kafir. Perintah perang tersebut pada dasarnya bukan bertujuan untuk menghilangkan kekafiran, akan tetapi perang untuk mempertahankan negara baru dan melindunginya, serta melindungi kebebasan dakwah. ${ }^{13}$ Perintah tersebut terdapat pada surat al-Nisa' ayat 95 bahwa tidaklah sama antara mukmin yang duduk (yang tidak ikut berperang) yang tidak mempunyai 'uzur dengan orang-orang yang berjihad di jalan Allah dengan harta mereka dan jiwanya. Allah melebihkan orang-orang yang berjihad dengan harta dan jiwanya atas orang-orang yang duduk satu derajat. kepada masing-masing mereka Allah menjanjikan pahala yang baik (surga) dan Allah melebihkan orang-orang yang berjihad atas orang yang duduk dengan pahala yang besar.

\section{Jihad dalam al-Qur'an}

Fu'ad Abdul Baqi ${ }^{14}$ dalam kitabnya al-Mu'jam al-Mufahras Li Alfadh alQur'an menjelaskan kata jihad dan derivasinya terulang dalam al-Qur'an sebanyak 41 kali. Kata tersebut terbagi dalam 19 surat. Penggunaan kata tersebut mempunyai bentuk yang variatif, adakalanya berupa Fi'il Madhi,

${ }^{13}$ Ahmad Al-Tayyeb and Dkk, Jihad Melawan Teror: Meluruskan Kesalahpahaman Tentang Khilafah, Takfir, Jihad, Hakimiyah, Jahiliyah Dan Ekstrimitas (Jakarta: Lentera Hati, 2016), 155.

${ }^{14}$ M. Fuad Abdul Baqi, Mu’jam Al-Mufahras (Kairo: Dar al-Had $\square$ st, 1996), 224-25.

Kodifikasia: Jurnal Penelitian Islam, Volume, 14 No. 1 Tahun 2020 
Mudlari', Amar dan Masdar. Selain itu juga terbagi dalam beberapa bentuk, baik Mufrad, Tasniyah ataupun Jama'.

Dalam al-Qur'an, pemahaman maknajihad dapat dikelompokkan dalam empat pesan utama; pertama, jihad yang bermakna perang; kedua, jihad yang berakna berpendapat (hujjah); ketiga, jihad yang bermakna berinfak di jalan Allah; dan terakhir adalah jihad yang memiliki makna bersungguhsungguh menolong dan menjalankan perintah agama. ${ }^{15}$ Keempat makna jihad tersebut memiliki kurun waktu tersendiri sesuai dengan keadaan muslim. Hal ini menunjukkan bahwa tidak bisa mencampuradukkan keempat makna tersebut dalam memaknai lafal jihad. Berikut contoh ayatayat yang memiliki makna seperti yang disebut di atas:

1. Jihad bermakna perang (melawan hawa nafsu)

Seperti yang dicontohkan dalam Q.S al-Ankabut ayat 6, Dan barangsiapa yang berjihad, maka sesungguhnya jihadnya itu adalah untuk dirinya sendiri. Sesungguhnya Allah benar-benar Maha Kaya (tidak memerlukan sesuatu) dari semesta alam.

Dalam kutipan ayat tersebut, terdapat kata jihad yang bermakna berperang dengan kesungguhan (melawan hawa nafsu). Dari banyak tafsir yang menjelaskan keterangan ayat tersebut, penulis baru menemukan kalimat jihad diartikan sebagai peperangan di medan perang adalah dari tafsir al-wajiz karya Prof. Dr. Wahbah Zuhaili. Selain dalam tafsir alwajiz, makna jihad dalam ayat tersebut memiliki arti kesungguhan dan perjuangan untuk diri sendiri dan perjuangan terhadap serangan orang kafir. Kesungguhan ini adalah bentuk perlawanan diri dalam menahan dan melawan hawa nafsu.

2. Jihad bermakna berpendapat

Dijelaskan dalam Surat al-Mumtahanah aya 1 yang artinya: Hai orang-orang yang beriman, janganlah kamu mengambil musuh-Ku dan musuhmu menjadi teman-teman setia yang kamu sampaikan kepada mereka (berita-berita Muhammad), karena rasa kasih sayang; padahal sesungguhnya mereka telah ingkar kepada kebenaran yang datang kepadamu, mereka mengusir Rasul dan (mengusir) kamu karena kamu beriman kepada Allah, Tuhanmu. Jika kamu benar-benar keluar untuk berjihad di jalan-Ku dan mencari keridhaan-Ku (janganlah kamu berbuat demikian). Kamu memberitahukan secara rahasia (beritaberita Muhammad) kepada mereka, karena rasa kasih sayang. Aku lebih mengetahui apa yang kamu sembunyikan dan apa yang kamu nyatakan. Dan barangsiapa di antara kamu yang melakukannya, maka sesungguhnya dia telah tersesat dari jalan yang lurus.

${ }^{15}$ Abu Nizhan, Buku Pintar Al-Qur'an (Jakarta: Qultum Media, 2008), 546. 
3. Jihad bermakna berinfaq

Dalam Q.S al-anfal: 72 Jihad bermakna berinfaq, isi ayat tersebut menjelaskan bahwa sesungguhnya orang-orang yang beriman dan berhijrah serta berjihad dengan harta dan jiwanya pada jalan Allah dan orang-orang yang memberikan tempat kediaman dan pertolongan (kepada orang-orang muhajirin), mereka itu satu sama lain lindungmelindungi. Dan (terhadap) orang-orang yang beriman, tetapi belum berhijrah, maka tidak ada kewajiban sedikitpun atasmu melindungi mereka, sebelum mereka berhijrah. (Akan tetapi) jika mereka meminta pertolongan kepadamu dalam (urusan pembelaan) agama, maka kamu wajib memberikan pertolongan kecuali terhadap kaum yang telah ada perjanjian antara kamu dengan mereka. Dan Allah Maha Melihat apa yang kamu kerjakan.

Wahbah Zuhaily ${ }^{16}$ mengklasifikasi jihad dalam ayat tersebut sebagai berikut:

a. Jihad dengan harta, Jihad dengan harta merupakan kategori jihad yang utama, yaitu dengan menginfakkan harta untuk dijadikan modal untuk berhijrah dan dijadikan pertahanan bagi agama, seperti mempersiapkan kuda-kuda perang dan pedang, serta untuk memenuhi kebutuhan orang Islam dalam peperangan.

b. Jihad dengan diri, artinya dengan menjadi aktor dalam melaksanakan peperangan, menghadapi musuh dan sabar menghadapi cobaan dan menghadapi kerasnya peperangan.

Jihad dengan harta menjadi prioritas utama karena dilihat darisisi kebutuhan, para mujahid yang menginfakkan hartanya lebih bermanfaat bagi orang banyak, karena secara langsung mereka akan memenuhi kebutuhan para pejuang ketika dalam peperangan. Pada dasarnya kedua jenis orang berjihad itu sama pentingnya dalam Islam, akan tetapi para mujahid yang menginfakkan hartanya dipandang memiliki kontribusi yang lebih dalam jihad karena harta yang mereka infakkan dapat mencukupi kebutuhan mujahid lain yang tidak menginfakkan harta.

4. Jihad bermakna bersungguh-sungguh menjalankan perintah agama Seperti yang dicontohkan dalam Q.S al-An'am:109, yang artinya mereka bersumpah dengan nama Allah dengan segala kesungguhan, bahwa sungguh jika datang kepada mereka sesuatu mu jizat, pastilah mereka beriman kepada-Nya. Katakanlah: "Sesungguhnya mukjizat-mukjizat itu hanya berada di sisi Allah". Dan apakah yang memberitahukan kepadamu bahwa apabila mukjizat datang mereka tidak akan beriman.

${ }^{16}$ Az-Zuhaili, Tafsir Al-Munir Fi Al-`aqidah Wa asySyar `iah Wa Al-Manhaj, 427.

Kodifikasia: Jurnal Penelitian Islam, Volume, 14 No. 1 Tahun 2020 
Dalam tafsirJalalain disebutkanbahwa (Merekabersumpah) orang-orang kafir penduduk Mekah (dengan nama Allah) dengan segala kesungguhan yang ada pada mereka dalam hal bersumpah (bahwa sungguh jika datang kepada mereka sesuatu mukjizat) sesuai dengan apa yang mereka minta (pastilah mereka beriman kepada mukjizat tersebut. Katakanlah) kepada mereka ("Sesungguhnya mukjizat-mukjizat itu hanya berada di sisi Allah.") Dialah yang akan menurunkan sesuai dengan apa yang dikehendaki-Nya karena sesungguhnya aku hanya seorang pemberi peringatan (dan apakah yang memberitahukan kepadamu) yang membuat kamu tentang keimanan mereka apabila mukjizat-mukjizat itu didatangkan; artinya kamu tidak akan mengetahui hal itu (bahwa apabila mukjizat itu datang mereka tidak akan beriman) berkat pengetahuan-Ku yang telah waspada sebelumnya. Dan menurut suatu qiraat memakai ta yakni tu'minuuna yang berarti khithab ayat ditujukan kepada orang-orang kafir. Menurut qiraat lainnya dibaca annahaa yang maknanya sinonim dengan Lafal la`alla atau menjadi ma'mul dari `amil sebelumnya. ${ }^{17}$

\section{Radikalisme sebagai Bentuk Jihad yang Salah}

Radikal berasal dari Bahasa Latin radix yang bermakna akar. Ia merupakan paham yang menghendaki adanya perombakan besar untuk mencapai kemajuan. ${ }^{18}$ Dalam Kamus Besar Bahasa Indonesia ${ }^{19}$ menyatakan bahwa radikalisme berasal dari kata "radiks" yang artinya pangkal, sumber, dasar, bagian bawah, awal mula dan akar. Radikalisme berarti paham atau aliran yang radikal dalam politik yang menginginkan perubahan atau pembaharuan sosial dan politik dengan cara kekerasan atau drastis, sikap ekstrem dalam aliran politik.Radikalisme menunjukan sesuatu penolakan dan perlawanan terhadap kondisi dan sistem yang ada. Lebih dari sekedar menolak, gerakan radikal juga berupaya menggantikan tatanan lama secara mendasar dan menyeluruh dengan tatanan lain. ${ }^{20}$ Karena kuatnya keyakinan idiologinya yang paling benar dan menafikan pandangan lain, kaum radikal kerap menampilkan sikap yang emosional dan terlibat kekerasan.

Fenomena radikalisme dalam Islam muncul sebagai akibat dari krisis identitas yang berujung pada reaksi terhadap Barat yang menyebarkan kolonialisme di Timur Tengah pada abad 20. Terpecahnya dunia Islam ke dalam berbagai Negara, bangsa dan proyek modernisasi yang dicanangkan

\footnotetext{
${ }^{17}$ Jalalain, Tafsir Al-Imamain Al-Jalalain (Bairut: Dâr Ibnu Katsir, n.d.), 278.

${ }^{18}$ Laisa, "Islam Dan Radikalisme," 3.

${ }^{19}$ Pusat Bahasa Departemen Pendidikan Nasional, Kamus Besar Bahasa Indonesia (Jakarta: PT. Gramedia Pustaka Utama, 2008), 919.

${ }^{20}$ Ridwan Al-Makassary and Dkk, Benih-Benih Islam Radikal Di Masjid: Studi Kasus Jakarta Dan Solo, 2010, 20.
} 
oleh pemerintahan sekuler, mengakibatkan umat Islam merasakan terkikisnya ikatan agama dan moral yang selama ini mereka pegang teguh. Hal ini menyebabkan munculnya gerakan radikal dalam Islam yang menyerukan kembali pada ajaran Islam yang murni sebagai sebuah penyelesaian.

Setiap muslim sejati tentulah merasa berkewajiban untuk menyiarkan Islam. Namun faktanya, dalam al-Qur'an tidak dtemukan satu dalil pun tentang berdakwah dengan menggunakan cara kekerasan. QS 2: 256 menyatakan bahwa: "Tak ada paksaan dalam agama" disertai dengan alasan sebagai berikut: "Jalan yang benar tampak jelas bedanya dengan jalan yangsalah". Ayat ini diturunkan setelah turunnya ayat yang mengizinkan perang, dankarenanya jelas bahwa izin menjalankan perang tak ada hubungannya dengan penyiaran agama.

Izin menjalankan perang diberikan kepada kaum muslimin karena mereka diserang atau dianiaya. QS 22:39-40 menyatakan : "Telah diizinkan (berperang)bagi orang-orang yang diperangi karena sesunguhnya mereka telah dianiaya. Dan sesunguhnya Allah benar-benar Maha Kuasa menolong mereka itu. (yaitu) orang-orang yang telah diusir dari kampung halaman mereka tanpa alasan yang benar, kecuali karena mereka berkata: 'Tuhan kami hanyalah Allah'. Dan sekiranya Allah tiada menolak (keganasan) sebagian manusia dengan sebagian yang lain, tentulah telah dirobohkan biara-biara, gereja-gereja, rumahrumah ibadat orang Yahudi da masjid-masjid yang di dalamnya banyak disebut nama Allah. Sesungguhnya Allah pasti menolong orang yang menolong (agama)Nya. Sesungguhnya Allah bena-benar Maha Kuat lagi Maha Perkasa.".

Jadi, baik dalam wahyu yang turun permulaan maupun wahyu yang turun belakangan, tak ada satu ayat pun yang berisi perintah untuk menyiarkan Islam dengan kekerasan atau dengan pedang. Sebaliknya hingga turun wahyu terakhir, perang hanya boleh dilakukan untuk membela diri. Tak ada satu contohpun dalam sejarah Nabi yang beliau menawarkan kepada perorangan ataukah kelompok untuk memilih antara perang atau Islam.

Harus diakui bahwa dalam catatan perjalanan sejarah Islam, banyak terjadi peristiwa dan tindakan radikalisme. Dari peristiwa pada masa khulafaur rasyiddin sampai sejarah perebutan kekuasaan oleh banyak golongan. Namun tentulah itu bukan ajaran Islam. Karena semangat Islam tentulah yang membawa kedamaian dan keselamatan. Tindakan radikalisme tersebut adalah kekerasan yang ditujukan terhadap kelompok dalam Islam sendiri atau kelompok agama lain dengan membawa simbol-simbol agama atau menggunakan agama sebagai alat jastifikasinya. Jika merujuk pada pengertian radikalisme maka yang disebut sebagai radikalisme tidak hanya yang dilakukan secara fisik, tapi juga kekerasan non fisik. Maka cara 
pandang yang membolehkan cara-cara kekerasan dalam menyelesaikan persoalan agama bisa masuk kategori radikal meskipun cara pandang itu belum mewujud dalam kenyataan.

Jika kita perhatikan terjadinya kekerasan atas nama agama, ilmuan dalam bidang sosiologi agama, politik maupun ilmu sosial lainya memberikan penjelasan sekurang-kurangnya terdapat beberapa penyebab mengapa orang bersedia melakukan tindakan kekerasan atas nama agama. Pertama, persoalan pemahaman keagamaan. Oleh sebab karena adanya keyakinan akan teks suci yang mengajarkan tentang terorisme dari kata jihad. ${ }^{21}$ Pemahaman keagamaan merupakan bagian penting dari kekerasan agama (radikalisme-terorisme) yang dilakukan. Kedua, radiakalisme-terorisme juga dikaitkan dengan adanya pemahaman tentang ketidakadilan politik, ekonomi dan hukum yang berjalan dalam sebuah negara. Sebuah rezim politik dan partai tertentu dianggap berlaku tidak adil kepada sekelompok masyarakat.

Ketiga, radikalisme-terorisme juga buruknya dalam hal penegakan hukum sehingga menimbulkan apa yang sering disebut sebagai ketidakadilan hukum. Penegakan hukum yang tidak berjalan dengan maksimal, sehingga menumbuhkan kejengkelan dalam perkara hukum yang ada dalam sebuah negara. Ketidakadilan hukum dianggap sebagai salah satu faktor yang masih dominan dalam sebuah negara termasuk di Indonesia, sehingga aparat penegak hukum sering menjadi sasaran kekerasan kaum radikalis-teroris. Peristiwa penembakan aparat kepolisian di beberapa daerah di Indonesia, seperti di Poso, Mataram, Solo, Mataram dan Jakarta adalah bukti-bukti yang menjelaskan kalau posisi dianggap tidak adil dalam menegakkan hukum.

Keempat, persoalan pendidikan yang lebih menekankan pada aspek ajaran kekerasan dari agama, termasuk pendidikan yang lebih menekankan aspek indoktrinasi, tidak memberikan ruang diskusi tentang suatu masalah. Oleh sebab itu, pendidikan semacam itu merupakan masalah lain lagi yang sangat mungkin mendorong terjadinya radikalisasi karena kebebalan perspektif pendidikan agama. Oleh sebab itu harus dipikirkan kembali pendidikan agama yang bersifat transformatif dan pembebasan pada umat manusia. Pendidikan agama tidak hanya mengajarkan persoalan jihad dalam makna kekerasan atau perang tetapi jihad dalam makna yang luas seperti memberantas kemiskinan, memberantas mafia hukum, memberantas politikuang dan partai yang buruk adalah jihad yang sesungguhnya harus dilakukan.

\footnotetext{
${ }^{21}$ Kuntowijoyo, Paradigma Islam Interpretasi Untuk Aksi (Bandung: Mizan, 1990), 24.
} 
Dalam rangka meminimalisir tindakan radikal yang mengatasnamakan agama, hal ini perlu dilakukan oleh berbagai pihak tanpa terkecuali. Terlebih dari lembaga pedidikan keagamaan seperti sekolah madrasah, dan pondok pesantren. Normatifnya, ilmu agama dalam lingkungan pesantren diajarkan dan dipraktikkan oleh para santri secara langsung. Maka santri, sudah seharusnya jika mampu menguasai ilmu pengetahuan tentang Islam secara lebih mendalam dan mampu memberikan energi positif dalam menyemaikan nilai-nilai Islam Rahmatan lil 'alamin. ${ }^{22}$

\section{Santri Sebagai Pengikis Radikalisme Beragama}

Santri adalah sebutan bagi mereka yang tinggal atau mencari ilmu di pondok pesantren. Kata "santri" berasal dari istilah shastri dalam bahasa India, kata shastri berasal dari shastra yang berarti buku-buku suci, buku-buku agama atau buku-buku tentang ilmu pengetahuan. ${ }^{23}$

Dalam bukunya Menggerakkan Tradisi: Esai-Esai Pesantren, Abdurrahman Wahid $^{24}$ menyebut tiga nilai terpenting yang lazim dikembangkan dalam pesantren. Nilai yang pertama adalah nilai ibadah. Seorang santri diajarkan dalam hal cara memandang kehidupan ini secara keseluruhan adalah sebagai ibadat. Nilai kedua yang muncul adalah kecintaan yang tinggi pada ilmu pengetahuan agama. Ilmu dan ibadat lalu menjadi identik sehingga muncul kecintaan yang mendalam pada ilmu-ilmu agama. Kecintaan ini dimanifestasikan dalam berbagai bentuk seperti penghormatan seorang santri y ang sangat dalam kepada ahli-ahli ilmu agama, kesediaan berkorban dan bekerja keras untuk menguasai ilmu-ilmu tersebut, dan kerelaan bekerja untuk nantinya mendirikan pesantrennya sendiri sebagai tempat menyebarkan ilmu-ilmu tersebu. Nilai utama ketiga yang berkembang di pesantren adalah keikhlasan atau ketulusan bekerja untuk tujuan-tujuan bersama.

Para pemimpin pondok pesantren seringkali menghubungkan ihsan dengan bentuk makna ikhlas. Keihlasan adalah ajaran Islam yang paling tinggi, Kyai Abdul Jalil menunjukkan tiga tingkatan ikhlas. Tingkatan ikhlas yang paling rendah adalah keikhlasan seorang muslim yang melaksanakan kewajiban-kewajiban agama hanya karena adanya perintah. Tingkatan ikhlas kedua adalah keikhlasan seorang muslim yang melaksanakan amalan ibadah bukan karena semata-mata menjalankan kewajiban, melainkan

${ }^{22} \mathrm{M}$, Strategi Pendidikan Islam Dalam Mengembangkan Manusia Indonesai Yang Berkualitas, 67.

${ }^{23}$ Zamakhsyari Dhofier, Tradisi Pesantren: Studi Pandangan Hidup Kyai Dan Visinya Mengenai Masa Depan Indonesia (Jakarta: LP3ES, 2011), 4.

${ }^{24}$ Abdurrahman Wahid, Menggerakkan Tradisi; Esai-Esai Pesantren (Yogyakarta: Lkis, 2001), 100.

Kodifikasia: Jurnal Penelitian Islam, Volume, 14 No. 1 Tahun 2020 
karena telah menjadi kebutuhan hidupnya. Tingkatan ikhlas ketiga adalah keikhlasan seorang muslim yang mengerjakan ibadah ritual dan sosial ssemata-mata untuk mendekatkan diri kepada Tuhan. ${ }^{25}$

Menurut Nurcholish Madjid, ${ }^{26}$ tujuan pembinaan santri pada pondok pesantren adalah "membentuk manusia yang memiliki kesadaran tinggi bahwa ajaran Islam merupakan nilai-nlai yang bersifat menyeluruh. Selain itu produk pesantren diharapkan memiliki kemampuan tinggi untuk mengadakan respons terhadap tantangan-tantangan dan tuntutantuntutan hidup dalam konteks ruang dan waktu". Jika mengikuti tujuan yang dikemukakan oleh Nurcholish, tergambar bahwa semua pondok pesantren telah mampu menjadikan manusia memiliki kesadaran Islam adalah nilai yang mencakup seluruh kehidupan. Pesantren sebagai lembaga pendidikan keagamaan sejak dahulu memainkan peranan yang strategis terutama dalam mempengaruhi pola pikir, pengetahuan, pemahaman, serta prilaku keagamaan masyarakat muslim Indonesia. Melalui pendidikan yang diselenggarakannya, pesantren berperan sebagai alat transformasi kultural dan sosial yang menyeluruh dalam kehidupan masyarakat, tidak hanya dalam bidang agama tetapi dalam segala aspek kehidupan.

Transformasi sosial yang telah dilakukan oleh pesantren dapat bermula dari watak pendidikan pesantren sebagai miniatur masyarakat, di mana para santri dengan fasih dapat belajar untuk sosialisasi dengan lingkungan internal maupun eksternal pesantren. Sebagai miniatur masyarakat, pesantren memiliki dinamika tersendiri dalam menghadapi perubahan sosial di masyarakat. Di tengah arus perubahan sosial dan tarik menarik pengaruh wacana keagamaan, pesantren memiliki peranan dalam membentuk karakter keagamaan santri dan masyarakat secara umum, terutama di tengah-tengah maraknya gerakan radikalisme yang berkembang.

Kurikulum menjadi modal utama dalam membangun kerangka pikir dan prilaku masyarakat, terutama santri yang akan terjun ke tengah masyarakat. Kurikulum yang ada di Pesantren pada dasarnya bersifat fundamental dan berpotensi dimaknai secara radikal, terutama yang bertumpu pada mata pelajaran akidah/ tauhid, fikih dan tafsir. Tiga pelajaran tersebut menyediakan perangkat pengetahuan untuk merespons kondisi sosial masyarakat. Ketiganya menyediakan konstruksi pemahaman keagamaan yang berpotensi pada kecenderungan pemahaman radikal, terutama dalam membahas persoalan jihad, kafir dan hukum Islam, apalagi jika dipahami secara dogmatis dan radikal, maka akan memiliki potensi

${ }^{25}$ Wahid, $146-47$.

${ }^{26}$ Nurcholish Madjid, Cita-Cita Politik Islam Di Era Reformasi (Jakarta: Paramadina, 1999), 6. 
radikalisme. Sebaliknya jika dipahami secara kontekstual atau moderat, bisa meminimalisasi potensi radikalisme.

Dalam Pelaksanaan penanaman nilai-nilai Islam moderat, hal-hal yang perlu dilakukan oleh lembaga pendidikan di Pesantren di antaranya adalah melalui keteladanan (modeling) para pengasuh, melalui kurikulum (proses pembelajaran), dan praktek pembiasaan sehari-hari. Beberapa strategi dalam pendidikan Islam moderat adalah sebagai berikut:

1. Melalui keteladanan (modeling) para pengasuh

Keteladanan (modeling) adalah contoh yang ideal yang selayaknya atau seharusnya diikuti di dalam komunitas pesantren. Keteladanan seorang kyai adalah merupakan cerminan prilaku yang diikuti dan dicontoh oleh para santrinya. Menurut Abdurahman Mas'ud ${ }^{27}$, dalam dunia pesantren, modeling, keteladanan, uswah hasanah diartikan sebagai tasyabbuh, proses identifikasi diri pada seseorang tokoh.

Dalam sebuah pondok pesantren, peran kyai sangat penting dan sangat berpengaruh di dalamnya. Kyai merupakan pemimpin tunggal yang memegang peran hampir mutlak. Kharisma seorang kyai di dalam pesantren menjadikan kyai sangat disegani dan dihormati oleh para ustadz maupun santrinya. Seorang kyai harus bisa menjadi suri tauladan bagi para santri di dalam pesantren. Untuk itu kyai sangat berpengaruh dalam hal pendidikan maupun tingkah laku, terutama dalam pembentukan sikap dan karakter santri. Terbentuknya karakter santri di dalam lingkungan pesantren tergantung bagaimana peran kepemimpinan kyai di dalamnya. Keberhasilan dari kepemimpinan kyai dalam membentuk karakter santri juga dipengaruhi oleh kharisma kyai yang kemudian diikuti oleh para santri.

2. Penanaman nilai-nilai moderasi melalui pembelajaran kitab dan pendidikan wawasan kebangsaan.

Penyelenggaraan pendidikan melalui pengajaran kitab-kitab kuning karangan ulama-ulama salaf merupakan bentuk optimal dalam mempelajari agama Islam. Hampir semua aspek keislaman dikaji dalampengajaran kitab, mulai dari Al-Qur'an, tauhid/ aqidah, fiqh, tafsir, hadist, tarikh (sejarah), bahasa, tasawuf/ akhlak sampai pada etika sosial dan budaya (muamalah). Pluralitas pemikiran yang terdapat dalam kajian-kajian kitab kuning yang dipelajari di pondok pesantren merupakan fenomena tersendiri bagi terbentuknya pandangan dan kepribadian para santri dalam memandang realita yang terjadi di masyarakat.

${ }^{27}$ Mas'ud, "Memahami Agama Damai Dunia Pesantren," xix.

Kodifikasia: Jurnal Penelitian Islam, Volume, 14 No. 1 Tahun 2020 
Didalam kajian kitab kuning, terdapat keberagaman (pluratitas) pendapat para ulama mengenai satu persoalan meskipun dalam satu kitab, bahkan bukan hanya perbedaan lintas madzhab, tetapi perbedaan pendapat ulama dalam satu madzhab. Pluralitas pemikiran para ulama ini menjadi fenomena tersendiri bagi terbentuknya wawasan para santri dalam memandang realita. Para santri kemudian terbentuk pola fikir yang inklusif, substantif, kontekstual dan moderat.

Kajian-kajian kitab kuning di pesantren tersebut menemukan signifikansinya dalam membentuk para santri yang berpandangan moderat. Disamping itu pesantren dapat dimaknai sebagai bagian tak terpisahkan dari dunia akademis dan intelektual. Pesantren seperti halnya dunia akademik dan memiliki ciri khas tersendiri, bertanggung jawab atas berbagai fenomena sosial yang berkembang dan berdampak negatif bagi kelangsungan hidup manusia. Dengan demikian pesantren sangat berpotensi untuk merespon paham-paham keagamaan yang ekstrim yang membahayakan kelangsungan hidup masyarakat dengan melakukan upaya rekonstruksi pemahaman masyarakat dengan mendasarkan keilmuan yang dimiliki kalangan pesantren.

Disamping penanaman melalui pengajaran kitab, pendidikan pesantren juga sangat perlu untuk diberi pendidikan mengenai wawasan kebangsaan. Karena hal ini merupakan salah satu pilar terbentuknya karakter Islam moderat. Wawasan kebangsaan merupakan pandangan seseorang mengenai bangsa dan negaranya. Wawasan kebangsaan terdiri dari kata wawasan dan kebangsaan. Wawasan berasal dari kata "wawas" yang dalam bahasa mengandung arti pandangan, tinjauan, penglihatan, tangggapan inderawi. Dalam istilah lain wawasan mengandung arti paham atau keyakinan tentang suatu hal, cara pandang, cara tinjauan dan caratanggapan inderawi. Kebangsaan berasal dari kata bangsa atau "nation" yang diartikan sebagai kelompok manusia yang berasal dari keturunan nenek moyang yang sama. Istilah kebangsaan umumnya dikaitkan dengan ciri-ciri yang menandai golongan bangsa yang mempunyai unsur-unsur berupa persaudaraan, keturunan, adat istiadat, sejarah dan sistem pemerintahan..$^{28}$ Dengan demikian kebangsaan merupakan hasil perkembangan dari dinamisasi rasa kebangsaan dalam mencapai cita-cita bangsa. Wawasan kebangsaan tersebut akhirnya melahirkan sesuatu paham kebangsaan atau nasionalisme, yaitu pikiranpikiran yang bersifat nasional, dimana suatu bangsa memiliki cita-cita kehidupan dan tujuan nasional.

\footnotetext{
${ }^{28}$ Mastuhu, Dinamika Sistem Pendidikan Pesantren (Jakarta: INIS, 1994), 54.
} 
Indonesia merupakan negara yang terdiri dari berbagai macam perbedaan baik suku, ras, bangsa, budaya, agama dan bahasa. Mengingat hal itu, untuk mencegah munculnya paham radikal dan menguatkan karakter Islam yang moderat perlu adanya penanaman wawasan kebangsaan. Tujuanya adalah agar para santri memiliki cakrawala pengetahuan mengenai fakta berbagai perbedaan yang ada di Indonesia dan menguatkan rasa nasionalisme. Dari sini para santri bisa berperan aktifditengah-tengah masyarakat yang plural dan ikut menciptakan suasana yang kondusif serta ikut andil dalam mencapai tujuan nasional.

3. Melalui praktek pembiasaan

Nilai-nilai Moderasi dalam kehidupan sehari-hari itu diwujudkan dalam tradisi yang berkembang di lingkungan pesantren dan masyarakat secara umum di luar pesantren (muslim Indonesia). Tradisi-tradisi itu merupakan bentuk aktualisasi dari ajaran moderasi yang telah ada sejak zaman Walisongo dan tetap dilestarikan. Tradisi yang berkembang ditengah-tengah masyarakat itu kemudian mendapatkan legitimasi dari kalangan pesantren tradisional. Berbicara tradisi, sebagaimana dalam kajian keilmuan di pesantren telah memiliki landasan yang kuat. Dalam kajian ushul fiqh, masalah tradisi (al-'urfu) mendapat perhatian cukup besar.

Dalam kaitan antara budaya atau tradisi dan agama paling tidak menurut Haedar Bagir (2017: 175-176) terdapat padangan positif, yakni sebagai sumber kearifan (wisdom) dan sebagai warisan hikmah ketuhanan. Tradisi yang berkembang di kalangan pesantren pada khususnya dan masyarakat pada umumnya merupakan sebagai sumber kearifan lokal untuk mewujudkan harmonisasi kehidupan di masyarakat.

Pesantren menemukan signifikansikansinya untuk mengajarkan nilainilai ajaran Islam melalui budaya, bukan hanya tentang materi apa yang ditawarkan, tetapi metodologi apa yang mesti dipakai agar tepat sasaran. Sebagaimana cara-cara yang dilakukan para Walisongo, cara yang damai, kultural, berangsur-angsur, populis (merakyat) tetapi efektif dan dinamis. Dalam membentuk karakter Islam moderat maka lingkungan harus memiliki budaya damai. Budaya damai yang dimaksud adalah budaya yang mencerminkan wajah Islam rahmatan lil 'alamin. Budaya damai ini di Pondok Pesantren secara kontinyu diajarkan dan dipraktekkan dalam asas praksis sebagai bagian dan ruh kehidupan pesantren. Salah satunya adalah penerapan sikap keseharian santri yang mengedepankan ikraman wa ta'ziman, baik kepada kyai maupun ustadz dan kepada sesama santri maupun orang lain. 


\section{PENUTUP}

\section{Kesimpulan}

Pemahaman mengenai jihad dikalangan masyarakat memang sangatlah beragam. Meski sebagain besar sudah memahami bahwa jihad tidak sama dengan perang mengangkat senjata, namun potensi untuk memahami jihad sebagai perilaku yang keras dalam menyikapi penyimpangan juga perlu diwaspadai. Jihad dalam pemahaman di kalangan pesantren sudah dipahami sebagai bentuk kepedulian social di sekitar lingkungan muslim. Namun, jika tindakan social tersebut sudah berkaitan dengan nilai religiusitas, maka akan menghasilkan kefahaman yang berbeda.

Kekerasan atas nama agama menjadi suatu hal yang tidak bisa dilegalkan. Ini berkaitan dengan pemahaman ayat al-Qur'an mengenai tidak adanya pemaksaan dalam beragama, dan penghormatan pada perbedaan yang ada. Namun pada praktiknya, tidaklah selalu sama dengan teori tentang Islam yang rahmatan lil 'alamin. Masih banyak pemikiran intoleransi baik dalam intern umat beragama dan antar umat beragama. Di kalangan pesantren, pemahaman akan tindakan kekerasan yang bertujuan untuk kebaikan telah disepakati bukan hal yang legal. Pada praktiknya, jika menemui kasus tertentu tentang penyesatan agama, penistaan agama tertentu, dan perusakan tempat ibadah agama tertentu hal tersebut terjadi inkonsistensi dalam penyikapan. Dan potensi untuk melakukan tindakan kekerasan tersebut terbesar adalah dilakukan di lingkungan keluarga terdekat, istri dan anak.

Pesantren sebagai tempat tinggal, fondasi pendidikan dan akhlaq seorang santri menjadi sangat urgen untuk diperhatikan dan diperbaiki tata kelolanya. Radikalisme selayaknya diwaspadai dan diminimalisir secepatnya. Dalam hal ini, pesantren sebagai lembaga pendidikan Islam dapat melakukan beberapa tindakan besar untuk mewujudkan nilai moderasi, di antaranya; mempersiapkan role model terbaik yang dalam hal ini adalah pimpinan pesantren/atau ustadz yang menyampaikan ilmu-ilmu keIslaman,; meanamkan nilai moderasi melalu pembelajaran kitab dan penanaman nilai-nilai wawasan kebangsaan; serta menginternalisasikan sikap moderasi dalam tingkah laku dan kebiasaan sehari-hari. 


\section{DAFTAR RUJUKAN}

Al-Haq, Muhammad Umar Jiau. Mencermati Aliran Sesat: Rekonstruksi Pemahaman Islam,. Bandung: Pustaka Islamika, 2011.

Al-Makassary, Ridwan, and Dkk. Benih-Benih Islam Radikal Di Masjid: Studi Kasus Jakarta Dan Solo, 2010.

Al-Tayyeb, Ahmad, and Dkk. Jihad Melawan Teror: Meluruskan Kesalahpahaman Tentang Khilafah, Takfir, Jihad, Hakimiyah, Jahiliyah Dan Ekstrimitas. Jakarta: Lentera Hati, 2016.

Ali, Maulana Muhammad. Islamologi (Dinul Islam). Jakarta: PT Ichtiar Baru - Van Hoeve, 1980.

Ar-Razi, Muhammad bin Abi Bakar bin 'Abdi al-Qadir. Mukhtar Al-Shahâh. Beirut: Maktabah Lubnân, 1986.

Az-Zuhaili, Wahbah. Tafsir Al-Munir Fi Al-`aqidah Wa asySyar `iah Wa AlManhaj. Damaskus: Darul Fikri, 1991.

Baqi, M. Fuad Abdul. Mu'jam Al-Mufahras. Kairo: Dar al-Hadỉst, 1996.

Dhofier, Zamakhsyari. Tradisi Pesantren: Studi Pandangan Hidup Kyai Dan Visinya Mengenai Masa Depan Indonesia. Jakarta: LP3ES, 2011.

Eliraz, Giora. Islam and Polity in Indonesia: An Intriguing Case Study. London: Hudson Institute, 2007.

Jalalain. Tafsir Al-Imamain Al-Jalalain. Bairut: Dâr Ibnu Katsir, n.d.

Kuntowijoyo. Paradigma Islam Interpretasi Untuk Aksi. Bandung: Mizan, 1990.

Laisa, Emna. "Islam Dan Radikalisme." Islamuna 3 (2014).

M, Thaha Chatib. Strategi Pendidikan Islam Dalam Mengembangkan Manusia Indonesai Yang Berkualitas. Yogyakarta: IAIN Walisongo, 1990.

Madjid, Nurcholish. Cita-Cita Politik Islam Di Era Reformasi. Jakarta: Paramadina, 1999.

Mandzur, Ibn. Lisân Al-'Arab. Kairo: Darul Ma'arif, 1119.

Mas'ud, Abdurrahman. "Memahami Agama Damai Dunia Pesantren." In Peranan Pesantren Dalam Mengembangkan Budaya Damai, edited 
by Nuhrison. Jakarta: Badan Litbang dan Diklat Kementrian Agama, 2010.

Mastuhu. Dinamika Sistem Pendidikan Pesantren. Jakarta: INIS, 1994.

Nasional, Pusat Bahasa Departemen Pendidikan. Kamus Besar Bahasa Indonesia. Jakarta: PT. Gramedia Pustaka Utama, 2008.

Nasir, Ridlwan. Mencari Tipologi Format Pendidikan Ideal: Pondok Pesantren Di Tengah Arus Perubahan. Yogyakarta: Pustaka Pelajar, 2010.

Nizhan, Abu. Buku Pintar Al-Qur'an. Jakarta: Qultum Media, 2008.

Wahid, Abdurrahman. Menggerakkan Tradisi; Esai-Esai Pesantren. Yogyakarta: Lkis, 2001.

Zada, Khamami. Islam Radikal: Pergulatan Ormas-Ormas Islam Garis Keras Di Indonesia. Jakarta: Teraju, 2002. 